\title{
ESTROGEN RECEPTOR AS A RESISTANCE MECHANISM TO TRASTUZUMAB
}

\author{
Ana Cvetanović1,2, Nikola Živković1,3, Miloš Kostić1, Miljana Džunić2, Bojan Jovanović4
}

\begin{abstract}
HER2-positive hormone-sensitive (HER2+/HR+) breast cancers have recently been singled out as a separate entity. It has been suggested that elevated estrogen receptor (ER) expression and/or activity may represent an avoidance mechanism or an alternative pathway leading to resistance to anti-HER2 therapy.

The aim of the study was to examine the disease outcome as the clinical benefit rate (CBR), progression-free survival (PFS), and overall survival (OS), both in the group of patients with HER2-positive metastatic breast cancer treated with first-line systemic therapy of trastuzumab along with chemotherapy and in patients with different status of hormone receptors HR+/HER2+ (ER+ and/or PR+/HER2+) compared to HR-/HER2+ (ER-/PR-/HER2+).

The study included 121 patients with pathohistologically confirmed HER2+ metastatic breast cancer treated with trastuzumab along with chemotherapy during 2017 and monitored until June 2020.

The mean age of the patients was $55.45 \pm 9.83$ years. $53.7 \%$ of the patients were HRpositive and $46.3 \%$ HR-negative. Progression-free survival was statistically significantly different regarding the HR status. Patients with HR- have longer PFS compared to patients with $\mathrm{HR}+(15$ and 8 months, respectively). Patients with HR- tumors have a $62 \%$ lower risk of disease progression compared to HR+ tumors (HR 0.382; 95\% CI 0.261-0.558, $\mathrm{p}<0.001$ ). The overall survival was statistically significantly different regarding the HR status $(p=0.034)$. Patients with HR- have longer survival compared to patients with HR+ (43 and 35 months, respectively). Hormone receptor negative tumors have a $43 \%$ lower risk of fatal outcome compared to hormone-sensitive tumors (HR 0.576; 95\% CI 0.342-0.972, $\mathrm{p}=0.039$ ).

Given that HR+/HER2- tumors have a poorer outcome with trastuzumab treatment, future clinical trials should focus on the combination of hormonotherapy and anti-HER2 therapy in this subtype of breast cancers.
\end{abstract}

Acta Medica Medianae 2021;60(1):38-47.

Key words: breast cancer, trastuzumab, resistance

\footnotetext{
${ }^{1}$ University of Niš, Faculty of Medicine, Niš, Serbia

${ }^{2}$ Clinic for Oncology, Clinical Center Niš, Niš, Serbia

${ }^{3}$ Clinic for Pathology, Clinical Center Niš, Niš, Serbia

${ }^{4}$ Center for Minimally Invasive Surgery, University Clinical

Center Niš, Niš, Serbia
}

Contact: Ana Cvetanović

4b Prvomajska St., 18000 Niš, Serbia

E-mail: ana.stankovic@yahoo.com

\section{Introduction}

Nowadays, breast cancer (BC) is a global problem given the fact that the incidence has suggested an epidemic and that the consequences affect all parts of society, starting from health, social, economic, as well as other factors. Breast cancer accounts for $25 \%$ of the total malignancy of the female population, i.e. it participates with $15 \%$ in mortality due to its malignancy in women (1).

HER2-positive breast cancer is characterized by a biologically aggressive clinical course, shorter progression-free survival, and shorter overall survival compared to HER2-negative breast cancer (2, $3)$. The discovery of efficient anti-HER2 therapies, new monoclonal antibodies that block the HER2 signalling pathway more effectively, which significantly prolonged the survival of HER2-positive breast cancers with a median of 56 months, is a historic result in the treatment of metastatic breast cancer (4). Trastuzumab is the first monoclonal antibody to be approved for the treatment of metastatic breast cancer, and in the last decade several more monoclonal antibodies, as well as small molecules of tyrosine inhibitors, have been approved (5).

HER2-positive hormone-sensitive (HER2+/ $\mathrm{HR}+$ ) cancers have recently been singled out as a 
separate entity. It has been suggested that elevated estrogen receptor (ER) expression and/or activity may represent an avoidance mechanism or an alternative pathway leading to resistance to anti-HER2 therapy $(6,7)$. Therefore, to see a potential role of ER as one of the mechanisms of resistance to trastuzumab, different HER2-positive breast cancer cell lines with de novo or acquired resistance after trastuzumab administration were examined. It has been observed that with constant inhibition of HER2 receptors, ER represents an alternative pathway by which HER2-positive cell lines proliferate and survive. The results of these cell line studies indicated that a more efficient blockade of these signalling pathways through the inhibition of both signalling pathways, HER2 and ER $(8,9)$, is necessary.

Studies conducted in early and locally advanced HER2-positive breast cancer have shown a correlation between the hormone receptor (HR) status and the efficacy of anti-HER2 therapy $(10,11)$. If the expression of hormone receptors, especially $E R$, is one of the mechanisms of resistance to trastuzumab and if this study shows that HR+/HER2+ patients treated with standard trastuzumab and chemotherapy have a worse disease outcome, i.e. shorter progression-free survival and overall survival compared to HR-/HER2+, it will indicate that further strategy of treatment of this subgroup of patients and further clinical research should focus on the combination of anti-HER2 and hormonotherapy that could represent a new standard in treatment. Hence, with the use of anti-HER2 and hormonotherapy, the use of cytostatic therapy would be avoided or reduced. In case the combination proves effective, it would improve the outcome of the disease and reduce toxicity, which would be a significant contribution to the treatment of such an aggressive subtype of breast cancer.

\section{The aim}

The aim of the study was to examine the disease outcome as the clinical benefit rate (CBR), progression-free survival (PFS), and overall survival (OS), both in the group of patients with HER2-positive metastatic breast cancer treated with systemic administration of trastuzumab with chemotherapy, as well as in patients with different status of hormone receptors $\mathrm{HR}+/ \mathrm{HER} 2+$ (ER+ and/or $\mathrm{PR}+$ / HER2+) compared to HR-/HER2+ (ER-/PR-/HER2+).

In addition, the study aimed to examine the differences in the disease outcome (PFS and OS) between patients with ER-positive receptors and ERnegative ones, as well as patients with PR-positive receptors and PR-negative ones.

\section{Patients and methods}

The study was conducted as a prospective observational study at the Oncology Clinic, Clinical Centre Niš. The study included 121 patients with pathohistologically verified HER2+ metastatic breast cancer treated with trastuzumab and chemotherapy during 2017 and monitored until June 2020.
The study involved patients with de novo diagnosed with HER2-positive metastatic breast cancer or with metastatic breast cancer after the disease-free interval of previously treated early or locally advanced breast cancer.

The inclusion criteria were as follows: patients $\geq 18$ years, ECOG performance status 0-2 (12), not receiving chemotherapy or targeted molecular therapy for the treatment of metastatic disease, disease measurability according to RECIST 1.1. criteria (13), appropriate haematological and biochemical parameters, left ventricular ejection fraction (LVEF) $>50 \%$. The exclusion criteria involved: metastatic spinal cord compression, symptomatic, untreated but actively progressive CNS metastases, rapid visceral progression, and severe cardiovascular disease.

Patients with metastatic breast cancer diagnosed after disease-free interval received:Paclitaxel at a dose of $175 \mathrm{mg} / \mathrm{m}^{2}$ intravenously (i.v.) once in three weeks (3qw) or docetaxel at a dose of 80-100 $\mathrm{mg} / \mathrm{m}^{2} \mathrm{i} . \mathrm{v}$. once in three weeks, a total of $6-8$ cycles concurrently with trastuzumab $600 \mathrm{mg}$ subcutaneously (s.c.) once in three weeks. After the completion of chemotherapy, trastuzumab was administered at the same dose of $600 \mathrm{mg}$ s.c. once in three weeks until the disease progression or unacceptable toxicity.

The following therapy was prescribed as premedication with paclitaxel: Amp.Dexason $20 \mathrm{mg}$ i.v., Amp.Synopen 20 mg i.v., Amp.Ondasan 8 mg i.v., Amp.Bensedin 5 mg i.m.

The following therapy was prescribed as premedication with docetaxel a day before therapy, on the day of therapy, and a day after therapy: Dexason $8 \mathrm{mg}$ in the morning and in the evening with Ranisan $150 \mathrm{mg}$ in the morning and in the evening per os.

Patients with de novo diagnosed metastatic breast cancer first received anthracycline-based chemotherapy given that the indications of the Health Insurance Fund of the Republic of Serbia allow the use of trastuzumab as first-line treatment of HER2-positive metastatic breast cancer after the administration of anthracycline in combination with taxanes. This group of patients first received 4 cycles of chemotherapy according to the AC/EC protocol every 3 weeks (Doxorubicin $60 \mathrm{mg} / \mathrm{m}^{2}$ or Epirubicin $90 \mathrm{mg} / \mathrm{m}^{2} \mathrm{i} . \mathrm{v}$. day 1 in combination with Cyclophosphamide $600 \mathrm{mg} / \mathrm{m}^{2} \mathrm{i} . \mathrm{v}$. day 1 ). The cycles are repeated every 3 weeks.

After the completion of anthracycline-based therapy, the above-described trastuzumab therapy in combination with taxanes was administered.

Before the onset of therapy, the cardiovascular status of each patient was assessed by echocardiographic examination with ejection fraction (EF) and ECG findings, and a complete blood test was done.

\section{Statistical data processing}

The data are presented in the form of the arithmetic mean and standard deviation, i.e. in the 
form of absolute and relative numbers. The length of the overall survival (OS) and progression-free survival (PFS) was calculated and compared with parameters examined by the Kaplan-Meier curve and a log-rank test. The univariate Cox regression analysis was used to calculate the hazard ratio (HR) of the tested predictor variables. The hypothesis was tested with a significance threshold of $p<0.05$. Statistical data processing was performed in the software package SPSS 16.0.

Progression-free survival (PFS) is defined as the time from the onset of the administration of systemic trastuzumab to disease progression or fatal outcome without disease progression.

Overall survival (OS) is defined as the time from the onset of the administration of systemic trastuzumab to fatal outcome caused by any reason, or last control check-up.

The clinical benefit rate (CBR) is the percentage of patients who achieved complete remission $(\mathrm{CR})$ + partial remission (PR) + stable disease (SD).

It was necessary to make a record of the exact date of the first trastuzumab therapy, as well as the exact date of disease progression, fatal outcome (if occurred), or the last control follow-up.

\section{Results}

The study included 121 patients, mean age $55.45 \pm 9.83$ years (min 29 years, max 75 years). The majority of the examined subjects were in menopause - 82 subjects $(67.8 \%), 23$ subjects $(19.0 \%)$ were not in menopause, whereas there was no data for 16 subjects (13.2\%).

In most patients, HER2 was determined only from the primary tumor $(86.8 \%)$. In less than $15.0 \%$ of the patients, HER2 was determined otherwise, from metastatic tumor biopsy samples or locoregional recurrences (Table 1 ).

In the examined population, most patients were initially diagnosed in stage IV of the disease $(43.8 \%)$, whereas $56.2 \%$ represented a relapse of previously treated breast cancer (Graph 1 ).

Fifty-nine patients (48.8\%) had ER-positive receptors, and 48 patients $(39.7 \%)$ had PR-positive receptors. Fifty-three point seven percent of the patients were HR-positive and $46.3 \%$ were HRnegative (Graph 2).

Table 1. Determination of HER2 status

\begin{tabular}{|l|cc||}
\hline \multicolumn{1}{|c|}{ HER2 determined from } & Number & $\%$ \\
\hline \hline Primary tumor & 105 & 86.8 \\
\hline Metastasis sample & 1 & 0.8 \\
\hline Recurrence & 5 & 4.1 \\
\hline Metachronous primary tumor & 7 & 1.7 \\
\hline Primary tumor and metastasis sample & 2 & 1.7 \\
\hline Primary tumor and recurrence & 121 & 100.0 \\
\hline \hline Total & & \\
\hline \hline
\end{tabular}

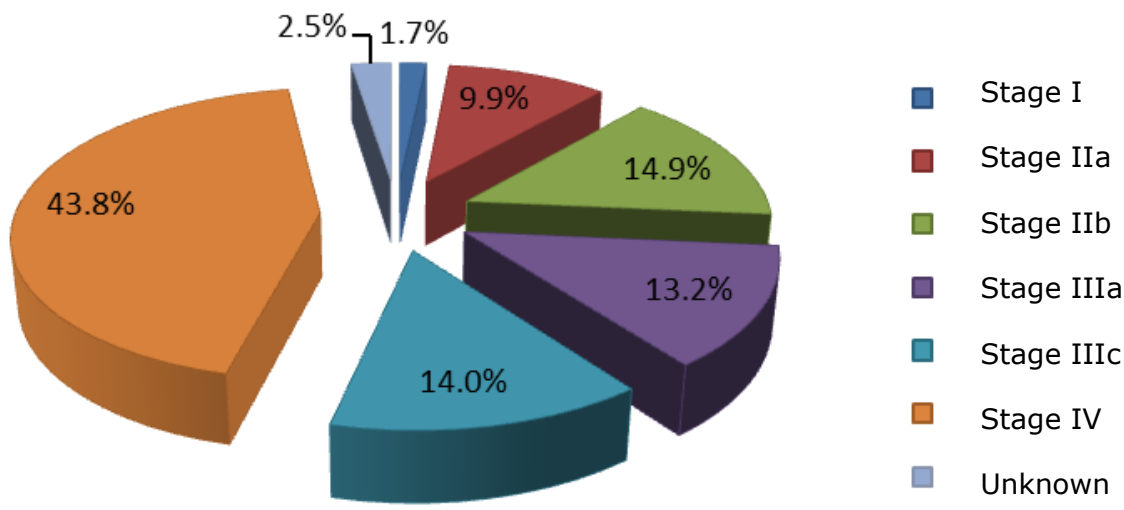

Graph 1. The initial stage of the disease in the studied population 


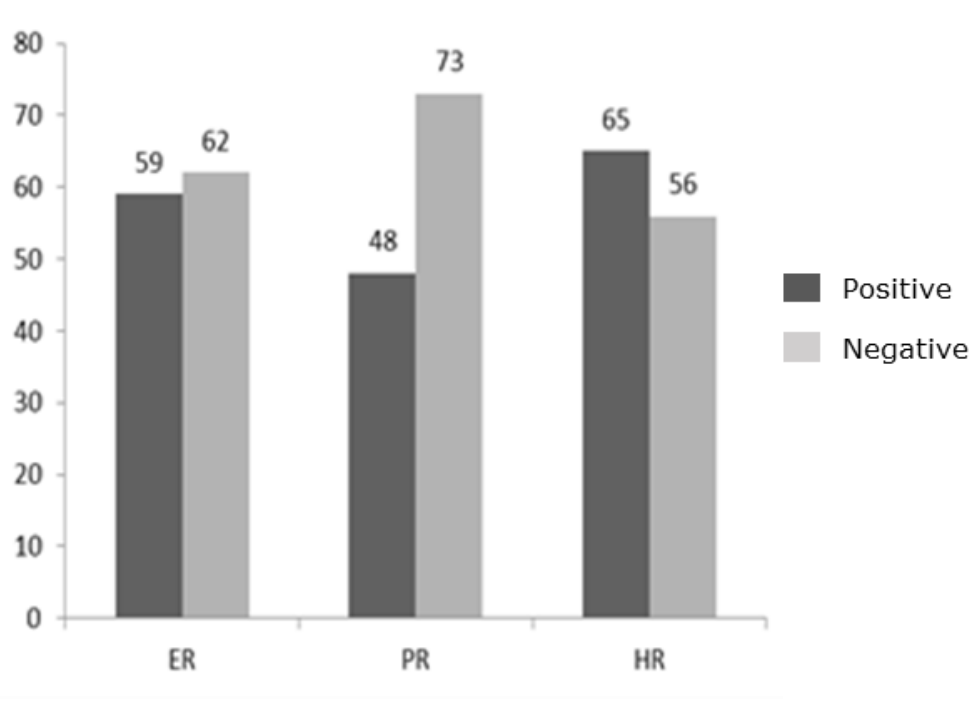

Graph 2. Distribution of $E R, P R$ receptors and $H R+/-$ in the studied population

\section{Response to administered therapy}

In the follow up period, most patients achieved partial remission of the disease $(38.0 \%)$, followed by stable disease $(31.4 \%)$, and disease progression (22.3\%). Complete remission was achieved in less than $10.0 \%$ of the monitored population $(8.3 \%)$. The clinical benefit rate was $77.7 \%$ (Table 2).

The distribution of the achieved response con- cerning HR- and HR+ was statistically signifi-cantly different $(p=0.005)$. Stable disease was found in $25.0 \% \mathrm{HR}-$ and $36.9 \% \mathrm{HR}+$. Partial remission developed in $53.6 \% \mathrm{HR}$ - and $24.6 \% \mathrm{HR}+$. Complete remission was present in $8.9 \% \mathrm{HR}-$ and $7.7 \% \mathrm{HR}+$. (Table 3).

The clinical benefit rate was statistically significantly higher in patients with HR- compared to $\mathrm{HR}+(p=0.029) .($ Graph 3$)$.

Table 2. Achieved response to administered therapy

\begin{tabular}{|l||cc||}
\hline \multicolumn{1}{|c|}{ Achieved response } & Number & \% \\
\hline \hline Stable disease & 38 & 31.4 \\
\hline Partial remission & 46 & 38.0 \\
\hline Disease progression & 27 & 22.3 \\
\hline Complete remission & 10 & 8.3 \\
\hline \hline Total & 121 & 100.0 \\
\hline
\end{tabular}

Table 3. Achieved response regarding HR status

\begin{tabular}{|l|cc|cc||c||}
\hline \multirow{2}{*}{\multicolumn{1}{|c|}{ Achieved response }} & \multicolumn{2}{c|}{ HR- } & \multicolumn{2}{c|}{ HR+ } & \multirow{2}{*}{ p } \\
\cline { 2 - 6 } & $\mathbf{n}$ & $\mathbf{\%}$ & $\mathbf{n}$ & $\mathbf{\%}$ & \\
\hline \hline Stable disease & 14 & 25.0 & 24 & 36.9 & 0.005 \\
\hline Partial remission & 30 & 53.6 & 16 & 24.6 & \\
\hline Disease progression & 7 & 12.5 & 20 & 30.8 & \\
\hline Complete remission & 5 & 8.9 & 5 & 7.7 & \\
\hline Clinical benefit rate & 49 & 87.5 & 45 & 69.2 & 0.029 \\
\hline
\end{tabular}




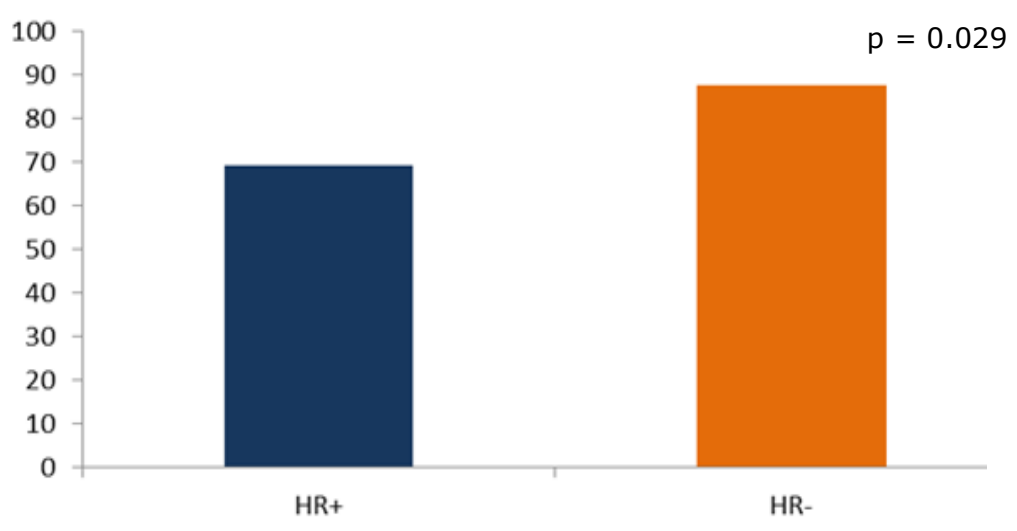

Graph 3. Clinical benefit rate in $H R+$ and $H R$ - patients

Treatment outcome - progression-free survival and overall survival

The average duration of the disease-free interval, progression-free survival and the overall survival in months is shown in Table 4.

The average time of the disease-free interval in the studied population was 11 months, and the mean duration of progression-free survival was statistically significantly different regarding the HR status. Patients with HR- have longer PFS compared to patients with $\mathrm{HR}+$ (15 and 8 months, respectively). Patients with HR- tumors have a $62 \%$ lower risk of disease progression compared to $\mathrm{HR}+$ tumors (HR $0.382 ; 95 \%$ CI 0.261-0.558, $\mathrm{p}<0.001$ ) (Graph 4).

Table 4. Disease-free interval, progression-free survival and overall survival in the studied population (in months)

\begin{tabular}{|l|c|c|}
\hline \multicolumn{1}{|c|}{ Time (months) } & AS \pm SD & Min-Max \\
\hline \hline Disease-free interval & $48.01 \pm 21.57$ & $19.00-134.00$ \\
\hline Progression-free survival & $11.36 \pm 6.64$ & $3.00-36.00$ \\
\hline Overall survival & $29.26 \pm 12.63$ & $6.00-66.00$ \\
\hline
\end{tabular}

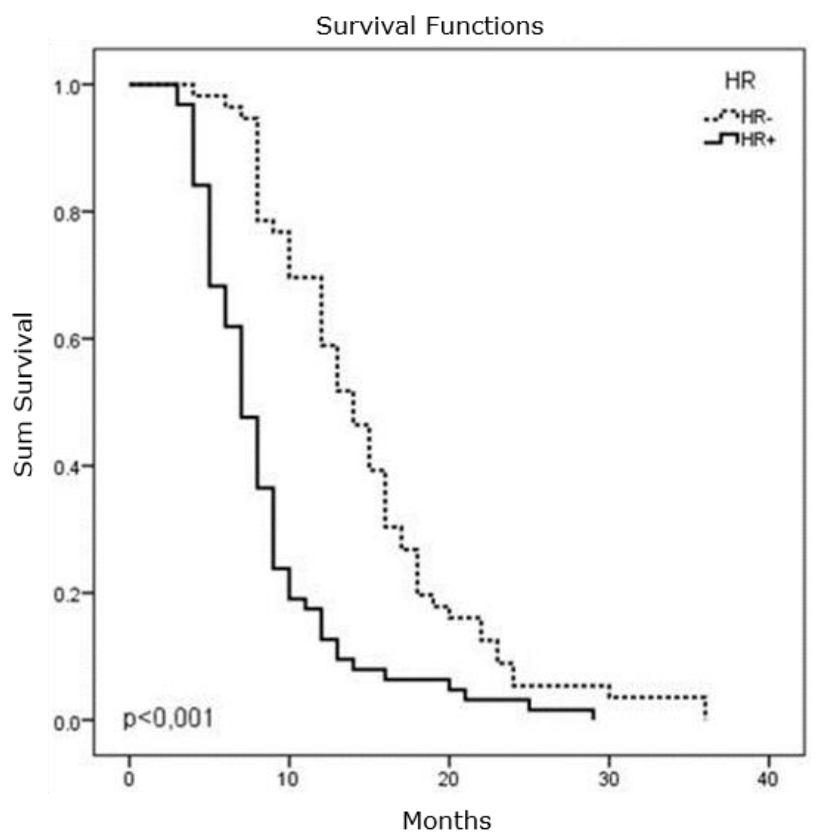

Graph 4. Kaplan-Meier curve of PFS regarding the HR status 
Progression-free survival was statistically significantly different regarding the status of PR and ER receptors ( $p<0.001$ and $p<0.001$, respectively). PR- have longer PFS compared to PR+ (13 and 8 months, respectively), i.e. they have a $59 \%$ lower risk of disease progression compared to PR+ receptors (HR 0.415; 95\% CI 0.282-0.611, p < 0.001).

Estrogen receptor-negative tumors (ER-) have longer PFS compared to estrogen receptor positive ones (ER+) (14 and 9 months, respectively), i.e. a $56 \%$ lower risk of disease progression (HR 0.439 ; 95\% CI 0.302-0.639, p < 0.001 )

Overall survival was statistically significantly different regarding the HR status $(p=0.034)$. HRpatients have longer survival compared to HR+ patients (43 and 35 months, respectively). Hormone-insensitive tumors have a $43 \%$ lower risk of fatal outcome compared to hormone-sensitive tumors (HR 0.576; 95\% CI 0.342-0.972, $\mathrm{p}=0.039$ ) (Graph 5).

In contrast to the duration of progression-free survival associated with the status of PR and ER, which was longer in ER- and PR-, no statistically significant difference in survival was found in ER+ $(p=0.070)$ or $P R+(p=0.291)$ in comparison to negative receptors.

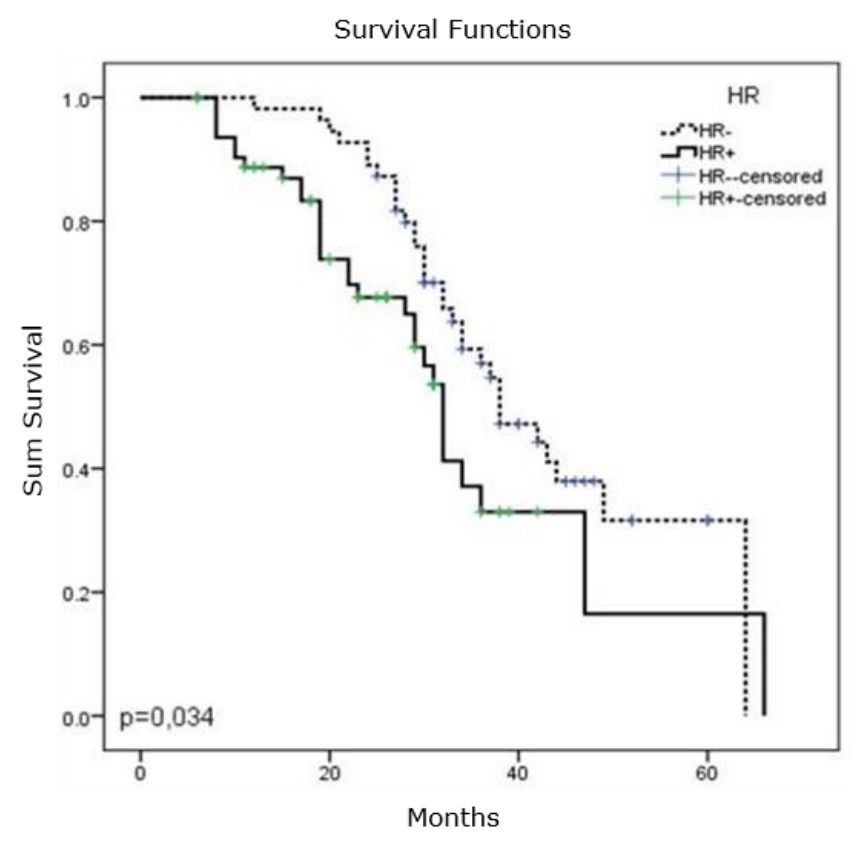

Graph 5. Kaplan-Meier curve of OS regarding the HR status

\section{Discussion}

After thorough processing and obtaining the results of this prospective study, the monoclonal antibody trastuzumab in combination with taxanebased chemotherapy has proved to be highly efficient and safe first-line therapy for metastatic HER2positive breast cancer.

The aim of this study was to examine the disease outcome as the clinical benefit rate (CBR), progression-free survival (PFS) and overall survival (OS) in the entire group of patients with HER2-positive metastatic breast cancer treated with systemic administration of trastuzumab in combination with chemotherapy, as well as to examine differences in the disease outcome (CBR, PFS, and OS) between patients with different hormone receptor status $\mathrm{HR}+/ \mathrm{HER} 2+$ (ER+ and/or PR+/HER2+) versus HR/HER2+ (ER-/PR-/HER2+). Given that a number of clinical studies have addressed this issue, our results will be compared primarily with two pivotal studies that introduced this combination of trastuzumab and taxanes into clinical practice, and afterward with smaller studies that examined the efficacy of this combination.

In the entire studied population, the overall response rate (ORR) was $46.3 \%$, whereas the clinical benefit rate (CBR) was $77.7 \%$ with the highest percentage of partial remission (PR) - 38\%, followed by stable disease (SD) - $31 \%$ and complete remission (CR) $-8 \%$. This rate is slightly lower than in a pivotal study by Marty et al. which compared the efficacy of combining docetaxel with trastuzumab to trastuzumab alone. The results of this study showed that the ORR was $61 \%$ and the CBR was $88 \%$ in the combined group because the partial remission rate was $54 \%$, which was higher than in our study, whereas the complete remission rate of $7 \%$ was comparable to our results (14). 
When talking about the objective response rate (ORR), our results are also comparable to the results of a pivotal study by Slamon et al. which compared the efficacy of combining chemotherapy (paclitaxel or anthracycline) with trastuzumab to first-line paclitaxel alone in metastatic HER2-positive breast cancer. In their HO648g study, the ORR was $50 \%$ in the combined therapy group, whereas in the paclitaxel and trastuzumab group it was $42 \%$ with $8 \% \mathrm{CR}$ and $34 \% \mathrm{PR}$, which is consistent with our results $(5,15)$. The results of these two pivotal studies incorporated the trastuzumab-taxane combination into clinical practice. They showed that PFS and OS were significantly longer in combination with trastuzumab compared to chemotherapy alone.

Progression-free survival was 11.7 months in the docetaxel group and 7 months in the paclitaxel group. Progression-free survival in our study amounted to 11 months, which is comparable, but also better compared to the results of pivotal trials.

Overall survival in the entire group of patients was 29 months, which is between the results of pivotal studies in which it amounted to 31 months in the docetaxel group and 25 months in the docetaxel with paclitaxel group. This result was expected given that our patients received both paclitaxel and docetaxel $(5,14,15)$.

The main aim of our study was to examine the differences in the disease outcome (CBR, PFS, OS) between patients with different hormone receptor status $\mathrm{HR}+/ \mathrm{HER} 2+(\mathrm{ER}+$ and/or $\mathrm{PR}+/ \mathrm{HER} 2+)$ compared to HR-/HER2+ (ER-/PR-/HER2+).

Resistance to trastuzumab has been intensively tested in recent years since it has been observed that not all HER2-positive cancers have the same benefit from anti-HER2 therapy. About $75 \%$ of breast cancers express ER and/or PR and belong to the group of hormone-sensitive cancers. About half of HER2-positive cancers express both ER and/or PR. In vitro and in vivo models suggest that there is a cross-talk of these two signalling pathways, which affects the response to therapy and treatment outcome of this group of patients.

It has recently been hypothesized that increased ER expression and/or activity may represent an avoidance mechanism or an alternative pathway leading to resistance to anti-HER2 therapy. For this reason, to realize the potential role of ER as one of the resistance mechanisms to trastuzumab, different HER2 positive breast cancer cell lines with de novo or acquired resistance to trastuzumab have been examined. It has been observed first in cell cultures that with constant inhibition of HER2 receptors, ER represents an alternative pathway by which HER2 positive cells proliferate and survive. In HR+/HER2+ cell lines in which the HER2 pathway was inhibited by lapatinib or the lapatinib/trastuzumab combination, resistance occurred via the ER signalling pathway which became the main promoter of cell growth and survival $(8,16)$. Other preclinical studies have shown that this response to anti-HER2 blockade is enhanced if fulvestrant hormonotherapy is added to lapatinib or trastuzumab (17). Studies on mice have shown that double blockade of HER2 and ER signalling pathways by different combinations of antiHER2 and hormonotherapy (lapatinib, trastuzumab, pertuzumab, gefitinib, tamoxifen, aromatase inhibitors) induce the best response to therapy in HER2+/HR+ breast cancer (18-22).

Regarding metastatic HER2+ breast cancer, there is little data on the difference in the efficacy of anti-HER2 therapy in luminal and non-luminal tumors. However, these data, as well as the results of our study, suggest that ER or PR expression may be one of the mechanisms of trastuzumab resistance. In metastatic HER2+ breast cancer, no study that tested the efficacy of anti-HER2 therapy in combination with first-line chemotherapy was designed to add hormonotherapy to anti-HER2 therapy as maintenance therapy until disease progression after the discontinuation of chemotherapy in the group with luminal tumors.

For that reason, there are no clear clinical recommendations, but based on the presented findings, it is assumed that the blockade of both signalling pathways would be a good treatment strategy in this subgroup of patients.

In our population of studied patients, there were 65 (53.7\%) HR-positive and 56 (46.3\%) HRnegative patients. PFS was statistically significantly different regarding the HR status ( $p<0.001)$. Patients with HR- had longer PFS compared to patients with $\mathrm{HR}+$ (15 and 8 months, respectively). PFS statistically significantly differed regarding PR and ER receptors ( $p<0.001$ and $p<0.001$, respectively). PR- patients had longer PFS compared to $\mathrm{PR}+$ ones (13 and 8 months). ER- patients had longer PFS compared to ER+ ones (14 and 9 months, respectively). Overall survival was statistically significantly different concerning the HR status ( $p=0.034)$. Patients with HR- had longer survival compared to patients with HR+ (43 and 35 months, respectively). Overall survival did not differ statistically significantly regarding PR $(p=0.291)$ and $E R$ receptors $(p=0.070)$ alone.

Brufsky et al. conducted a retrospective analysis to record differences in treatment outcome in patients with HR-positive and HR-negative tumors in metastatic HER2-positive cancer treated with trastuzumab as monotherapy or in combination with chemotherapy. This analysis included patients from three clinical studies: the already described phase III of the pivotal study by Slamon et al. which showed the efficacy of the combination of paclitaxel with trastuzumab in first-line treatment (469 patients), then a study by Cobleigh et al. in which trastuzumab was tested as monotherapy in the second and third line of treatment (222 patients), as well as the phase II study in which trastuzumab was tested in the first line of treatment in standard and escalated doses with 114 patients. A total of 269 out of 596 patients $(45 \%)$ had HR+/HER2+ tumors, whereas 255 out of 596 patients (43\%) had HER2+/HR-

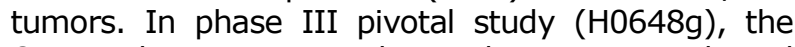
ORR and TTP were similar in the trastuzumab and chemotherapy group for patients with HR+ and HRtumors (ORR, 58\% vs 51\%; TTP, 7.6 vs 7.3 months, respectively). Overall survival was longer in the group with hormone-sensitive tumors (29.4 and 24.1 months, respectively) compared to the group with HR- tumors, which is contrary to our results. The hormone receptor status affected neither the 
efficacy of trastuzumab as first-line monotherapy regarding the objective response to therapy (ORR $33 \%$ [ $95 \%$ CI, $20 \%-50 \%$ ] vs $34 \%$ [ $95 \%$ CI $20.5 \%$ $-50 \%$ ] for HR-positive and HR-negative tumors, respectively) nor overall survival (OS 24.5 vs 20.5 months, for HR-positive and HR-negative tumors). The efficacy of trastuzumab in the second and third line of treatment was similar in terms of the hormone receptor status $(5,23-25)$.

Montemurro et al. conducted a retrospective analysis with 227 patients from 11 institutions treated with trastuzumab with chemotherapy in metastatic HER2-positive breast cancer. Out of a total of 227 patients, $49 \%$ had a hormone-sensitive tumor. High ER expression (more than $30 \%$ of cells) was associated with less benefit from the combination of trastuzumab and chemotherapy (HR 0.422; $\mathrm{p}=0.009)$. In patients with $\mathrm{HR}+$ tumors $(1 \%$ of tumor cells), hormone therapy added to trastuzumab as maintenance therapy after the completion of chemotherapy was associated with significant benefit in PFS compared to cases in which it was not added (HR 0.521; 95\% Cl, 0.3325-0.836; $\mathrm{p}=$ 0.007 ) (26). In our study, only 16 patients received hormone therapy as maintenance therapy and it was shown that the administration of hormone therapy in combination with trastuzumab in HR+ patients had a statistically significant effect on PFS (15 and 6 months, respectively, $p<0.001$ ). So far, no study has been designed to confirm this concept, however, retrospective data, as well as data from preclinical and neoadjuvant and adjuvant treatment studies suggest the efficacy of this combination.

Another retrospective analysis was conducted on patients treated at the University Hospital in Italy (Udine) from January 2004 to July 2012 from all subtypes of metastatic breast cancer treated with multiple lines of therapy, i.e. a maximum of 4 lines. Patients with luminal A and HER2-positive tumors had the best prognosis. Regarding HER2-positive tumors, HR+ tumors had a better treatment outcome compared to HR-ones (OS: 55.3 and 26.0 months, respectively; PFS: 17.5 and 8.1 months, respectively). Patients with non-visceral bone metastases had a better treatment outcome in comparison to patients with liver or lung metastases (27). In our study, patients with visceral metastases had statistically significantly longer PFS compared to those with non-visceral metastases $(p=0.018)$, nevertheless, overall survival did not differ substantially ( $p=$ 0.638 ).

In the largest prospective observational study registHERcarried out in the United States, a subanalysis was done on 530 patients (out of 1023) who were HER2-positive and HR-positive. Progres- sion-free survival (PFS) and overall survival (OS) were the primary aim. HR+/HER2+ patients treated in the first line of metastatic breast cancer with the combination of trastuzumab and hormonotherapy had significantly longer PFS compared to those who received only hormonotherapy (13.8 and 4.8 months, respectively; HR $0.37,95 \%$ CI: $0.22-0.60)$. Compared to patients treated with trastuzumab and chemotherapy in the first line of treatment, patients treated with trastuzumab with chemotherapy and hormonotherapy had longer PFS (20.4 and 9.5 months, respectively, HR:0.53, 95\% CI:0.42-0.68) and a significantly lower risk of fatal outcome (HR:0.50, 95\% CI:0.36-0.70). Sequential administration of chemotherapy with hormonotherapy showed greater benefit on overall survival compared to concurrent administration (HR:0.48, 95\% CI:0.26 -0.89 ). The conclusion of this analysis, which actually reflects real world data, was that dual blockade of both ER and HER2 signalling pathways, with or without chemotherapy, was clearly associated with benefits in treatment outcome, i.e. longer PFS and OS compared to anti-HER2 therapy alone (28).

\section{Conclusion}

Based on the results of the conducted study in the entire group of patients with HER2-positive metastatic breast cancer treated with systemic trastuzumab with chemotherapy in the first line of treatment, it was concluded that the outcome of treatment (CBR, PFS, OS) was statistically significantly different regarding the HR status. Patients with HRhave longer PFS compared to patients with HR+ (15 and 8 months, respectively), as well as longer OS (43 and 35 months, respectively). Hormone-insensitive tumors have a $43 \%$ lower risk of fatal outcome compared to hormone-sensitive tumors (HR 0.576; 95\% CI 0.342-0.972, $\mathrm{p}=0.039$ ).

Previous results indicate that results related to the influence of the hormone receptor status on the outcome of trastuzumab treatment in metastatic HER2-positive breast cancer are inconsistent. The question is whether the combination of anti-HER2 therapy with hormonotherapy without the administration of chemotherapy is a good treatment strategy. In metastatic HER2+ breast cancer, no study examining the efficacy of anti-HER2 therapy in combination with first-line chemotherapy has been designed so that after the discontinuation of chemotherapy, in the luminal tumor group, hormone therapy is added to anti-HER2 therapy as maintenance therapy to disease progression. Therefore, future clinical research should be focused in that direction. 


\section{References}

1. Jemal A, Bray F, Center MM, Ferlay J, Ward E, Forman D. Global cancer statistics. CA Cancer J Clin 2011; 61:69-90. [CrossRef][PubMed]

2. Tandon AK, Clark GM, Chamness GC, Ullrich A, McGuire WL. HER-2/neu oncogene protein and prognosis in breast cancer. J Clin Oncol 1989;7:1120-8. [CrossRef][PubMed]

3. Slamon DJ, Clark GM, Wong SG, Levin WJ, Ullrich A, McGuire WL. Human breast cancer: correlation of relapse and survival with amplification of the HER2/neu oncogene. Science 1987;235:177-82. [CrossRef][PubMed]

4. Swain SM, Kim SB, Cortés J, Ro J, Semiglazov V, Campone $M$, et al. Pertuzumab, trastuzumab, and docetaxel for HER2-positive metastatic breast cancer (CLEOPATRA study): overall survival results from a randomised, doubleblind, placebo-controlled, phase 3 study. Lancet Oncol 2013;14:461-71. [CrossRef][PubMed]

5. Slamon DJ, Leyland-Jones B, Shak S, Fuchs $H$, Paton $V$, Bajamonde $A$, et al. Use of chemotherapy plus a monoclonal antibody against HER2 for metastatic breast cancer that overexpresses HER2. N Engl J Med 2001;344:783-92. [CrossRef][PubMed]

6. Rexer $\mathrm{BN}$, Arteaga CL. Intrinsic and acquired resistance to HER2-targeted therapies in HER2 geneamplified breast cancer: mechanisms and clinical implications. Crit Rev Oncog 2012;17:1-16. [CrossRef][PubMed]

7. Chung A, Cui X, William Audeh, Giuliano A. Current status of anti-her2 therapies: predicting and overcoming herceptin resistance. Clin Breast Cancer 2013; 13(4):223-32. [CrossRef][PubMed]

8. Wang YC, Morrison G, Gillihan R, Guo J, Ward RM, Fu $X$, et al. Different mechanisms for resistance to trastuzumab versus lapatinib in HER2-positive breast cancers - role of estrogen receptor and HER2 reactivation. Breast Cancer Res 2011;13(6):R121.

[CrossRef][PubMed]

9. Montemurro $\mathrm{F}, \mathrm{Di}$ Cosimo $\mathrm{S}$, Arpino G. Human epidermal growth factor receptor 2 (HER2)-positive and hormone receptor-positive breast cancer: new insights into molecular interactions and clinical implications. Ann of Oncol 2013;24:2715-24. [CrossRef][PubMed]

10. Baselga J, Bradbury I, Eidtmann H, Di Cosimo S, de Azambuja E, Aura C, et al. Lapatinib with trastuzumab for HER2-positive early breast cancer (NeoALTTO): a randomised, open-label, multicentre, phase 3 trial. Lancet 2012;379:633-40. [CrossRef][PubMed]

11. Gianni L, Pienkowski T, Im YH, Roman L, Tseng LM, Liu MC, et al. Efficacy and safety of neoadjuvant pertuzumab and trastuzumab in women with locally advanced, inflammatory, or early HER2-positive breast cancer (NeoSphere): a randomised multicentre, open-label, phase 2 trial. Lancet Oncol 2012; 13:25-32. [CrossRef][PubMed]

12. Oken MM, Creech RH, Tormey DC, Horton J, Davis TE, McFadden ET, et al.Toxicity and response criteria of the eastern cooperative oncology group. Am J Clin Oncol 1982;5:649-55. [CrossRef][PubMed]

13. Eisenhauer EA, Therasse P, Bogaerts J, Schwartz LH, Sargent D, Ford R. et al. New response evaluation criteria in solid tumours:Revised RECIST guideline (version 1.1). Eur J Cancer 2009;45:228-47. [CrossRef][PubMed]

14. Marty M, Cognetti $F$, Maraninchi D, Snyder R, Mauriac $L$, Tubiana-Hulin $M$, et al. Randomized Phase II Trial of the Efficacy and Safety of Trastuzumab Combined
With Docetaxel in Patients With Human Epidermal Growth Factor Receptor 2-Positive Metastatic Breast Cancer Administered As First-Line Treatment: The M77001 Study Group. J Clin Oncology 2005;23(19): 4265-74. [CrossRef][PubMed]

15. Baselga J. Herceptin alone or in combination with chemotherapy in the treatment of HER2-positive metastatic breast cancer: Pivotal trials. Oncology 2001;61:14-21. [CrossRef][PubMed]

16. Xia W, Bacus S, Hegde P, Husain I, Strum J, Liu L, et al. A model of acquired autoresistance to a potent erbB2 tyrosine kinase inhibitor and a therapeutic strategy to prevent its onset in breast cancer. Proc Natl Acad Sci USA 2006;103:7795-800. [CrossRef][PubMed]

17. Liu L, Greger J, Shi H, Liu Y, Greshock J, Annan R, et al. Novel mechanism of lapatinib resistance in HER2positive breast tumor cells: activation of AXL. Cancer Res 2009;69:6871-8. [CrossRef][PubMed]

18. Nahta R, O'Regan RM. Therapeutic implications of estrogen receptor signaling in HER2-positive breast cancers. Breast Cancer Res Treat 2012;135:39-48. [CrossRef][PubMed]

19. Munzone E, Curigliano G, Rocca A, Bonizzi G, Renne G, Goldhirsch A, et al. Reverting estrogen-receptornegative phenotype in HER-2 overexpressing advanced breast cancer patients exposed to trastuzumab plus chemotherapy. Breast Cancer Res 2006;8:R4. [CrossRef][PubMed]

20. Giuliano M, Hu H, Wang YC Fu X, Nardone A, Herrera $S$, et al. Upregulation of ER signaling as an adaptive mechanism of cell survival in HER2-positive breast tumors treated with anti-HER2 therapy. Clin Cancer Res 2015;21:3995-4003. [CrossRef][PubMed]

21. Arpino G, Gutierrez C, Weiss H, Rimawi M, Massarweh $S$, Bharwani $L$, et al. Treatment of human epidermal growth factor receptor 2-overexpressing breast cancer xenografts with multiagent HER-targeted therapy. J Natl Cancer Inst 2007;99(9):694-705. [CrossRef][PubMed]

22. Rimawi MF, Wiechmann LS, Wang YC, Huang C, Migliaccio I, Wu MF, et al. Reduced dose and intermittent treatment with lapatinib and trastuzumab for potent blockade of the HER pathway in HER-2/neu overexpressing breast tumor xenografts. Clin Cancer Res 2011;17(6):1351-61. [CrossRef][PubMed]

23. Brufsky A, Lembersky B, Schiffman K, Lieberman G, Paton V. Hormone Receptor Status Does Not Affect the Clinical Benefit of Trastuzumab Therapy for Patients with Metastatic Breast Cancer. Clin Breast Cancer 2005;6(3):247-52. [CrossRef][PubMed]

24. Cobleigh MA, Vogel CL, Tripathy D, Robert NJ, Scholl $S$, Fehrenbacher $L$, et al. Multinational study of the efficacy and safety of humanized anti-HER2 monoclonal antibody in women who have HER2-overexpressing metastatic breast cancer that has progressed after chemotherapy for metastatic disease. J Clin Oncol 1999;17:2639-48. [CrossRef][PubMed]

25. Vogel CL, Cobleigh MA, Tripathy D, Gutheil JC, Harris $L N$, Fehrenbacher $L$, et al. Efficacy and safety of trastuzumab as a single agent in first-line treatment of HER2-overexpressing metastatic breast cancer. J Clin Oncol 2002;20:719-26. [CrossRef][PubMed]

26. Montemurro F, Rossi V, Rocca MC, Martinello R, Verri E, Redana S, et al. Hormone-Receptor Expression and Activity of Trastuzumab With Chemotherapy in HER2Positive Advanced Breast Cancer Patients. Cancer 2012;118(1):17-26. [CrossRef][PubMed] 
27. Bonotto $M$, Gerratana L, Poletto $E$, Driol $P$, Giangreco $M$, Russo S, et al. Measures of Outcome in Metastatic Breast Cancer: Insights From a Real-World Scenario. The Oncologist 2014;19:608-15. [CrossRef][PubMed]

28. Tripathy D, Kaufman PA, Brufsky AM, Mayer M, Yood $\mathrm{MU}$, Yoo $B$, et al. First-line treatment patterns and clinical outcomes in patients with HER2-positive and hormone receptor-positive metastatic breast cancer from registHER. Oncologist 2013;18:501-10. [CrossRef][PubMed]

\title{
ESTROGEN RECEPTOR KAO MEHANIZAM REZISTENCIJE NA TRASTUZUMAB
}

\author{
Ana Cvetanović1,2, Nikola Živković1,3, Miloš Kostić1, Miljana Džunić2, Bojan Jovanović4
}

\author{
${ }^{1}$ Univerzitet u Nišu, Medicinski fakultet, Niš, Srbija \\ ${ }^{2}$ Klinika za onkologiju, Klinički centar Niš, Niš, Srbija \\ ${ }^{3}$ Centar za patologiju, Klinički centar Niš, Niš, Srbija \\ ${ }^{4}$ Centar za minimalno invazivnu hirurgiju, Univerzitetski klinički centar Niš, Niš, Srbija \\ Kontakt: Ana Cvetanović \\ Prvomajska 4b, 18000 Niš, Srbija \\ E-mail: ana.stankovic@yahoo.com
}

HER2 pozitivi hormonosenzitivni (HER2+/HR+) karcinomi od nedavno se izdvajaju kao poseban entitet. Postoji pretpostavka da povišena ekspresija i/ili aktivnost estrogen receptora (ER) može predstavljati mehanizam izbegavanja ili alternativni put koji dovodi do rezistencije na anti-HER2 terapiju.

Cilj rada bio je ispitati ishod bolesti kao stopu kliničke koristi (CCR - Clinical benefit rate), vreme do progresije bolesti (PFS) i ukupno preživljavanje (OS), kako u celoj grupi bolesnica sa HER2 pozitivnim metastatskim karcinomom dojke lečenih sistemskom primenom trastuzumaba uz hemioterapiju, tako i između bolesnica sa različitim statusom hormonskih receptora HR+/HER2+ (ER+ i/ili PR+/HER2+) u odnosu na HR-/HER2+ (ER-/PR-/HER2+).

Studijom je obuhvaćena 121 bolesnica sa patohistološki verifikovanim HER2+ metastatskim karcinomom dojke, koje su lečene tokom 2017. godine, primenom trastuzumaba sa hemioterapijom i praćene sve do juna 2020. godine.

Prosečna starost bolesnica bila je 55,45 godina $\pm 9,83$ godine. HR pozitivno bilo je $53,7 \%$ bolesnica, a HR negativno $46,3 \%$ bolesnica. Vreme do progresije bolesti statistički se značajno razlikuje u odnosu na status HR. Bolesnice sa HR- imaju duži PFS u odnosu na bolesnice sa HR+ (15 meseci prema 8 meseci). Bolesnice sa HR- tumorima imaju za $62 \%$ niži rizik od progresije bolesti u odnosu na HR+ tumore (HR 0,382; 95\%CI 0,261 - 0,558; p < $0,001)$. Ukupno preživaljavanje statistički se značajno razlikuje u odnosu na status HR ( $p=$ $0,034)$. Bolesnice sa HR- imaju duže preživljavanje u odnosu na bolesnice sa HR+ (43 meseca prema 35 meseci). Hormononesenzitivni tumori imaju za $43 \%$ manji rizik od smrti u odnosu na hormonosenzitivne tumore (HR 0,576; 95\%CI 0,342-0,972; $p=0,039$ ).

$\mathrm{S}$ obzirom na to da HR+/HER2- tumori imaju gori ishod lečenja trastuzumabom, buduća klinička ispitivanja bi trebalo da budu usmerena na kombinaciju hormonoterapije i anti-HER2 terapije kod ovog podtipa karcinoma.

Acta Medica Medianae 2021;60(1):38-47.

KIjučne reči: karcinom dojke, trastuzumab, rezistencija 